九州大学学術情報リポジトリ

Kyushu University Institutional Repository

\title{
Insecticidal Effectiveness of Thiourea Derivatives
}

Kondo, Shigeo

Laboratory of Pesticide Chemistry, Faculty of Agriculture, Kyushu University

Maekawa, Kazuyuki

Laboratory of Pesticide Chemistry, Faculty of Agriculture, Kyushu University

https://doi.org/10.5109/22892

出版情報: 九州大学大学院農学研究院紀要. 20 (2)，pp.97-104，1976-02. Kyushu University バージョン：

権利関係 : 
J. Fac. Agr., Kyushu Univ., 20, 97-104 (1976)

\title{
Insecticidal Effectiveness of Thiourea Derivatives
}

\author{
Shigeo Kondo and Kazuyuki Maekawa \\ Laboratory of Pesticide Chemistry, Faculty of Agriculture, \\ Kyushu University, Fukuoka \\ (Received November 28, 1975)
}

\begin{abstract}
As to about forty thiourea derivatives and some thiol compounds, effects on pupation and imago emergence of housefly larvae were examined by feeding and dipping tests. As the result, it was elucidated that $\mathrm{N}$-benzoyl- $\mathrm{N}^{\prime}-(p$-dimethylamino $)$-phenylthiourea, 3 -(p-chlorophenyl)-thioureide-propionic acid and $\mathrm{N}-(3,4$-methylenedioxy)-benzoyl-N'$\left(3^{\prime}, 6^{\prime}\right.$-dichloro-2'-methoxy)-phenylthiourea inhibited markedly the imago emergence, but inhibited the pupation little. Moreover, some of the effective compounds restrained the anterior inhibition, suggesting that the inhibitory activity was concerned with depriving of metals.
\end{abstract}

Thiourea has been known as an antimetabolite for larvae of housefly, Musca domestica L. (Negherbon, 1959). Some derivatives of thiourea exhibited a rodenticidal activity (Tokumitsu, 1973), an antituberculous activity (Fujikawa et al., 1968, 1971, 1972), herbicidal (Everest-Todd, 1969; Pyne et al., 1974), fungicidal (Noguchi et al., 1969), and insect chemosterilantal (Oliver et al., 1971, 1973; Fye and Oliver, 1974). These activities have been presumed to be due to depriving metals by thiourea (Uzumasa and Okura, 1950). However, it seems that there are no detailed studies on thiourea derivatives as insecticide. As an attempt to develop pesticides disturbing metamorphosis of noxious insects, present paper deals with the investigation on insecticidal effect of thiourea derivatives by feeding and dipping tests to housefly.

As the result, it was found that some derivatives inhibited strongly both of pupation and imago emergence, and not a few others inhibited the latter only.

\section{EXPERIMENTALS}

\section{Feeding and dipping test}

Compounds used were purchased or synthetized. The syntheses of the compounds will be reported elsewhere.

\section{Feeding test}

Each compound was added in the artificial diet comprised of powdered yeast and wheat bran $(1: 1)$ to give the desired final concentration. One hundred larvae on second day after hatching were placed in a beaker $(100 \mathrm{ml})$ containing the diet $(25 \mathrm{~g})$, the testing compound (usually $50 \mathrm{mg}$ ) and water $(25 \mathrm{ml})$, then reared at $25^{\circ} \mathrm{C}$. The number of the pupation and the imago emergence were counted occasionally. 


\section{Dipping test}

Twenty final instar larvae were dipped in $0.5 \%$ acetone (or methanol) solution of each compound for 10 seconds. After 24 hours the number of pupae was counted, and the imago emergence was also examined afterwards.

The results obtained are presented in Tables 1 and 2. From these experiments, it was inferred that for the revelation of the activity in general one

Table 1. Insecticidal effectiveness of thiourea derivatives to housefly (feeding test, $100 \mathrm{ppm}$ otherwise indicated).

\begin{tabular}{|c|c|c|c|c|}
\hline No & Compound & $\begin{array}{l}\text { Substituent } \\
\text { (R) }\end{array}$ & $\begin{array}{l}\text { Pupa emer- } \\
\text { gence }(\%)\end{array}$ & $\begin{array}{c}\text { Imago emer- } \\
\text { gence }(\%)\end{array}$ \\
\hline & Thiourea & & & $14^{2\rangle}$ \\
\hline & Thiosemi carbazide & & 0 & 0 \\
\hline 1 & (O) $-\mathrm{NH}-\mathrm{C}(\mathrm{S})-\mathrm{NH}-\mathrm{R}$ & -0 & 92 & 58 \\
\hline 2 & $" 1$ & (O) & 82 & 67 \\
\hline 3 & "l & -(ㄱ) $-\mathrm{NO}_{2}$ & 38 & 23 \\
\hline 4 & $" 1$ & (a) $-\mathrm{SO}_{3} \mathrm{H}$ & 98 & 90 \\
\hline 5 & $" 1$ & $-\widehat{O}, \mathrm{~N}$ & 79 & 95 \\
\hline 6 & $\prime \prime$ & & 85 & 85 \\
\hline 7 & "I & $-\mathrm{CH}_{3}$ & 83 & 84 \\
\hline 8 & "l & $-\mathrm{CH}_{2}-\mathrm{CH}=\mathrm{CH}_{2}$ & 73 & 84 \\
\hline 9 & $!$ & $-\mathrm{C}_{2} \mathrm{H}_{4} \mathrm{OH}$ & 91 & 67 \\
\hline 10 & $-\mathrm{NH}-\mathrm{C}(\mathrm{S})-\mathrm{NH}-\mathrm{R}$ & -O) & 97 & 89 \\
\hline 11 & $" \prime$ & $-\mathrm{CH}_{2}-\mathrm{CH}=\mathrm{CH}_{2}$ & 94 & 83 \\
\hline 12 & $\mathrm{NH}-\mathrm{C}(\mathrm{S})-\mathrm{NH}-\mathrm{R}$ & -0 & 79 & 95 \\
\hline 13 & $" 1$ & $-\mathrm{CH}_{2}-\mathrm{CH}=\mathrm{CH}_{2}$ & 98 & 81 \\
\hline
\end{tabular}




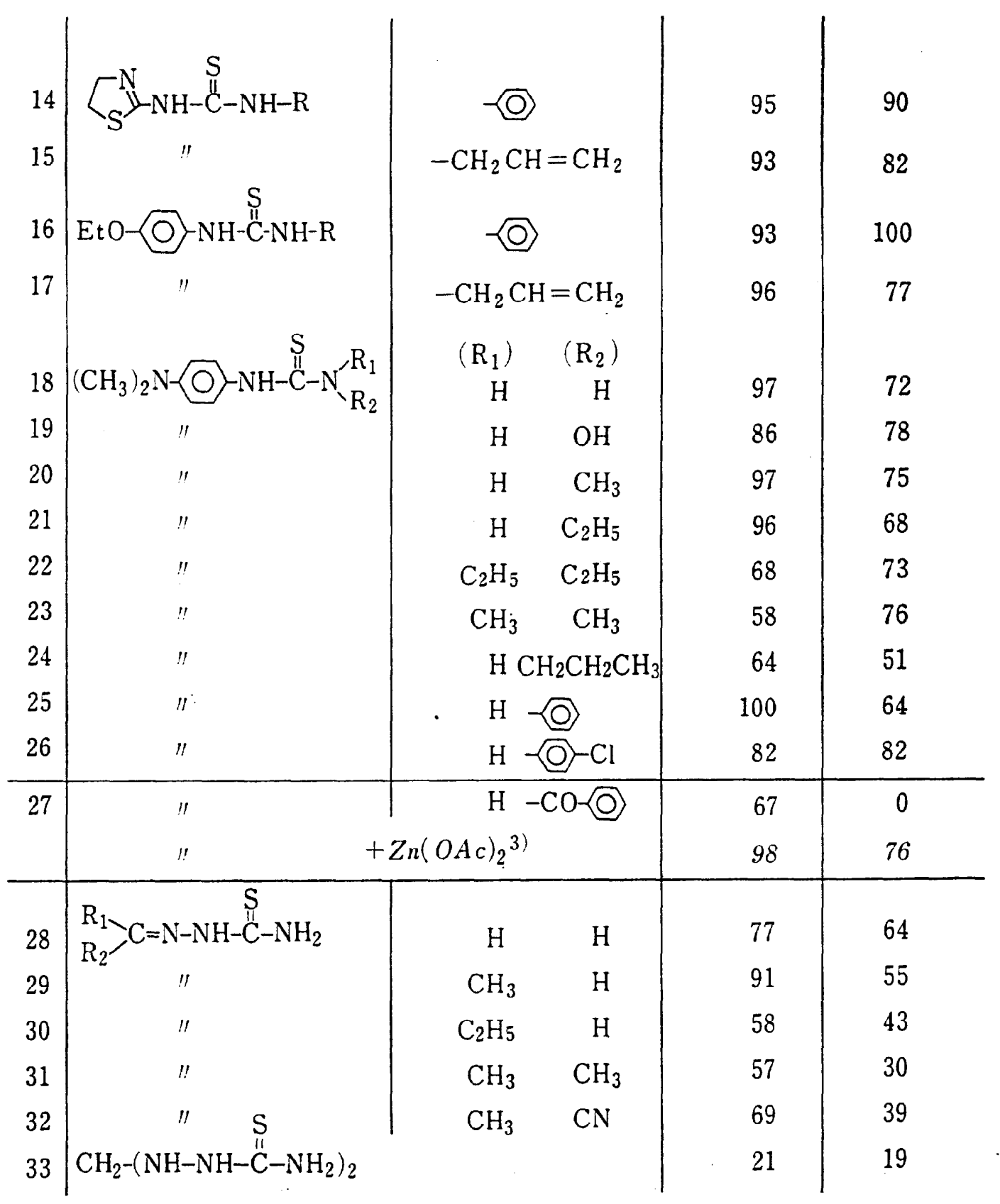

amino-group of thiourea-derivatives was requisite to be free (compounds 30,31 , 32 , and 33 ). Compounds 27,34 , and 35 did not inhibit so much the pupation, while they inhibited strongly the imago emergence. As these compounds possess another functional group besides $=\mathrm{C}=\mathrm{S}$, it is supposed that this functional group contributes to the revelation of the activity.

On the other hand, compounds 3 and 45 which have $\mathrm{NO}_{2}$ or $\mathrm{CN}$ group inhibited pupation in parallel with imago emergence. Thus, it was inferred that they acted non-specifically as a poison. Furthermore, the obvious delay of pupal and imago emerged stages was observed in comparison with control in some of these active compounds (Fig. 1). 


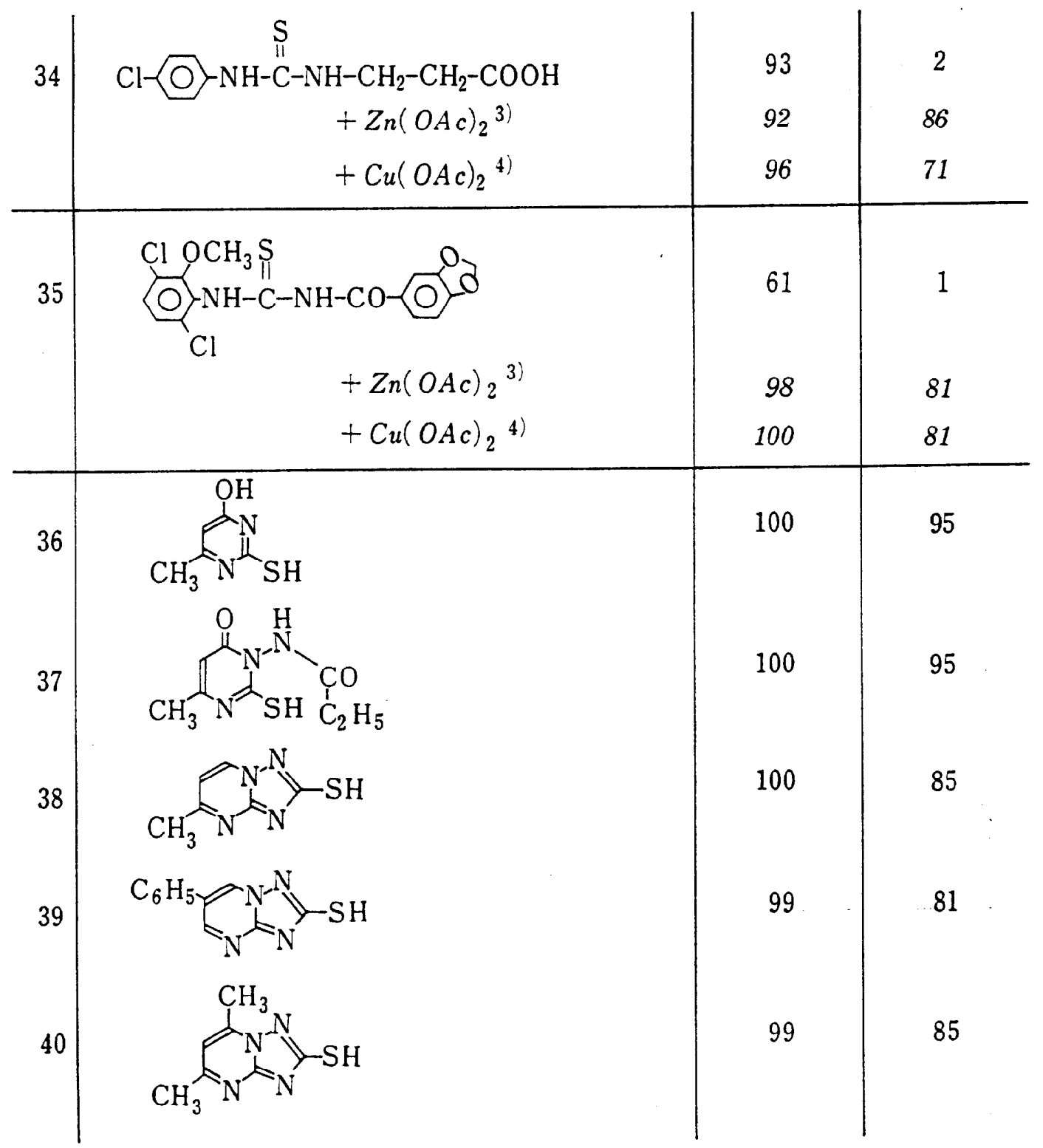

\section{Morphological changes in the pupal stage}

Morphological changes in the pupal stage of housefly larvae treated with these compounds are summarized in Table 3. Larvae fed with thiourea (in concentration of $100,500 \mathrm{ppm}$ ) fell in the shape of pupa-larva intermediate. They pupated, retaining a form of larval stage, and a great many of them was a rod like shape, but some of them had curved form. By feeding phenobarbital, one of urea derivatives, larvae were restrained almost from the growth, and resulted in small pupae (in conc. of $500 \mathrm{ppm}$ ) which were one half or one third in comparison with normal pupae. These abnormal or small pupae could not emerge by half.

\section{Effect on anterior inhibition}

Housefly larvae are generally ligated at position I as shown in Fig. 2. This 


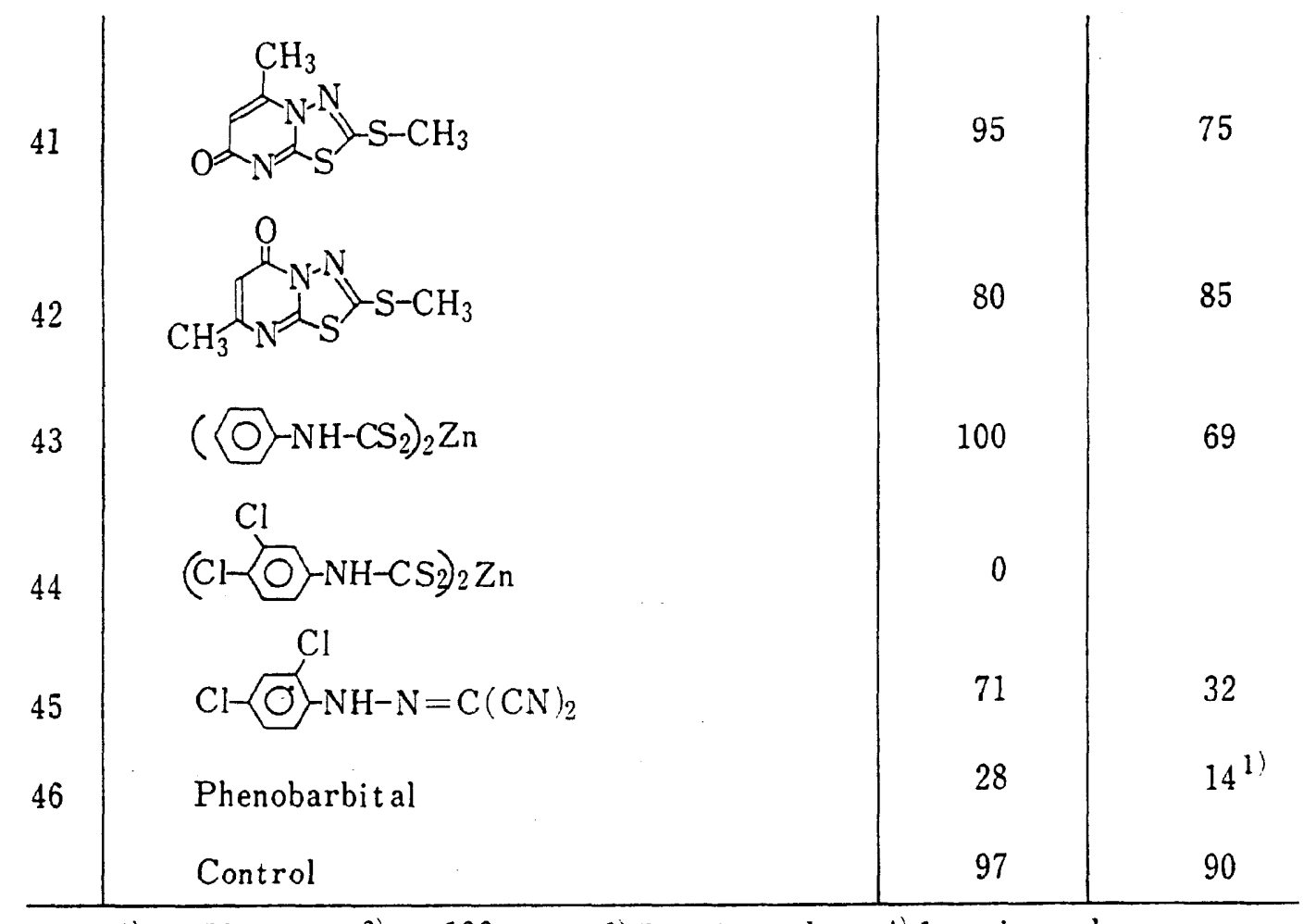

1) at $500 \mathrm{ppm}$, 2) at $100 \mathrm{ppm}$, 3) 5 equiv. mole, 4) 1 equiv. mole

Table 2. Dipping test of mature larvae.

\begin{tabular}{c|c|c}
\hline Compound $^{1)}$ & Pupation in 24 hrs. (\%) & Imago emergence (\%) \\
\hline Thiourea & 90 & 90 \\
Phenylthiourea & 30 & 70 \\
1 & 80 & 90 \\
3 & 100 & 80 \\
27 & 45 & 90 \\
30 & 65 & 80 \\
31 & 50 & 85 \\
32 & 75 & 80 \\
33 & 60 & 80 \\
34 & 45 & 100 \\
35 & 50 & 60 \\
44 & 60 & 5 \\
45 & 0 & 100 \\
\hline Control (CHOH) & 90 & 100 \\
\hline (acetone) & 95 & \\
\hline
\end{tabular}

1) conc. $0.5 \%$

technique aims at placing prothoracic glands which secrete ecdysone in the anterior position, or destroying prothoracic glands (Chino et al., 1974). However, ligated larvae showed sometimes abnormal pupation in which only posterior position pupated, or failed completely to pupate. This situation varies very much, 


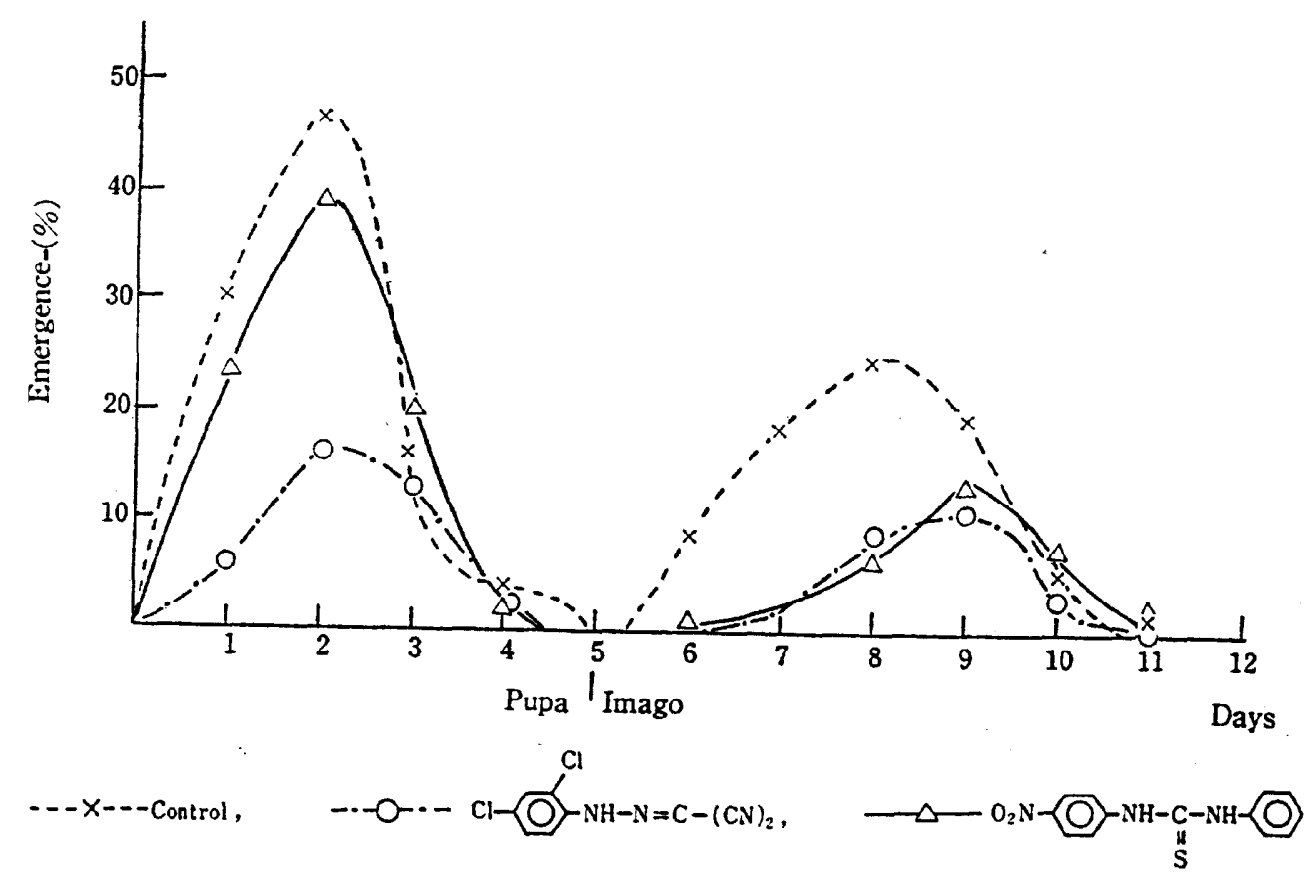

Fig. 1. Effect of thiourea derivatives on pupation and imago emergence of housefly larvae.

Table 3. Morphological change on puparium stage.

\begin{tabular}{|c|c|c|}
\hline Compound & Treatment & Feature \\
\hline $\begin{array}{l}\text { Thiourea } \\
\mathrm{CH}_{2}-\left(\mathrm{NH}-\mathrm{NH}-\mathrm{C}(\mathrm{S})-\mathrm{NH}_{2}\right)_{2} \\
\text { 4-Methyl-2-thiouracil } \\
\text { Piperonylbutoxide } \\
\text { Phenobarbital }\end{array}$ & $\begin{array}{l}\text { oral }(0.01 \% \text { in diet }) \\
\text { dipping }(0.1 \%) \\
\text { oral }(0.05 \% \text { in diet })\end{array}$ & $\begin{array}{l}\text { pupa-larva intermediate } \\
\text { " } \\
\text { small pupa } \\
\text { pupa-larva intermediate } \\
\text { non ecdysis, small pupa }\end{array}$ \\
\hline
\end{tabular}

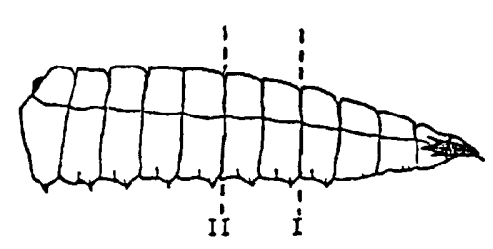

Fig. 2. Ligating position of larva.

if the ligating position is moved to the position II (Price, 1970). These abnormal pupations of ligated larvae have been named as an anterior inhibition. As the course of this inhibition, it was supposed recently by Ratnasiri and Fraenkel (1974) that oxygen-deficiency in the tissue by damage of trachea caused by the ligation was principal reason. They suggested also that supply of insufficient ecdysone, an excess of juvenile hormone and hormonal unbalance might participate in this phenomenon. Thereupon, the investigation on the effect of thiourea 
Table 4. Effect of thiourea derivatives on anterior inhibition.

\begin{tabular}{|c|c|c|c|c|}
\hline Compound & Pupa & at & & nent \\
\hline Thiourea & 3 & 1 & 6 & 0 \\
\hline $\begin{array}{r}\text { Phenylthiourea } \\
+\mathrm{Cu}^{2+} \\
+\mathrm{Zn}^{2+}\end{array}$ & $\begin{array}{l}0 \\
1 \\
1\end{array}$ & $\begin{array}{l}7 \\
3 \\
0\end{array}$ & $\begin{array}{l}2 \\
5 \\
8\end{array}$ & $\begin{array}{l}1 \\
l^{11} \\
I^{11}\end{array}$ \\
\hline 1 & 3 & 1 & 5 & 1 \\
\hline $\begin{array}{l}27 \\
+\mathrm{Cu}^{2+} \\
+\mathrm{Zn}^{2+}\end{array}$ & $\begin{array}{l}2 \\
1 \\
0\end{array}$ & $\begin{array}{l}1 \\
0 \\
0\end{array}$ & $\begin{array}{l}5 \\
3 \\
8\end{array}$ & $\begin{array}{l}2 \\
6^{1)} \\
2^{11}\end{array}$ \\
\hline $\begin{array}{l}34 \\
+\mathrm{Cu}^{2+} \\
+\mathrm{Zn}^{2+}\end{array}$ & $\begin{array}{l}1 \\
2 \\
0\end{array}$ & $\begin{array}{l}5 \\
I \\
I\end{array}$ & $\begin{array}{l}4 \\
5 \\
6\end{array}$ & $\begin{array}{l}0 \\
2^{11} \\
3^{11}\end{array}$ \\
\hline 44 & 5 & 2 & 1 & 2 \\
\hline 45 & 0 & 5 & 2 & 3 \\
\hline $\begin{array}{l}\text { Ecdysterone } \\
\text { Control }\end{array}$ & $\begin{array}{l}1.3 \\
2\end{array}$ & $\begin{array}{l}1.7 \\
1.7\end{array}$ & $\begin{array}{l}5 \\
5\end{array}$ & $\begin{array}{l}2 \\
1.3\end{array}$ \\
\hline
\end{tabular}

$$
\overbrace{\rightarrow \text { white }}^{\rightarrow \text { colored }}
$$

1) Larvae were immersed beforehand for $20 \mathrm{sec}$. in $5 \%$ aqueous solution of copper or zinc acetate, then treated similarly as the other examples.

derivatives on the anterior inhibition was undertaken.

The testing method is as following: 10-30 final instar larvae were dipped in acetone containing each compound at a concentration of $0.5 \%$ for $10 \mathrm{sec}$. at $25^{\circ} \mathrm{C}$, then ligated immediately at the position II. After 48 hours, the pupation of the ligated larvae was observed. Larvae were immersed beforehand for $20 \mathrm{sec}$. in $5 \%$ aqueous solution of copper or zinc acetate, then treated similarly with the sample solutions. The results obtained are illustrated in Table 4.

From these results, it was concluded that ecdysterone did not have any effect on the anterior inhibition, however, some of thiourea derivatives restrained markedly that phenomenon. Especially, bifunctional compounds such as phenylthiourea and 34,45 , namely the group which did not inhibit so much the pupation, but restrained the imago emergence, showed clearly this effect. This fact might be ascribed to that these compounds functioned essentially as metaldeprival. Furthermore, considering from the effect of compound 44, and 34 or 35 and zinc-acetate, zinc probably took a great part in this phenomenon.

\section{REFERENCES}

Chino, H., S. Sakurai, T. Ohtaki, N. Ikekawa, H. Miyazaki, M. Ishibashi and H. Abuki 1974 Biosynthesis of $\alpha$-eedysone by prothoracic glands in vitro. Science, $183: 529-530$ 
Everest-Todd, S., 1969 Herbicides containing 3-methylphenyl-N, $\mathrm{N}^{\prime}$-dimethylthiourea. Brit. Pat., 1, 154, 250, [Chem. Abst., 71: 59954h]

Fujikawa, F., K. Hirai, T. Hirayama, T. Matsunashi, Y. Nakanishi, K. Kumoto, T. Shimizu, C. Sakaki, Y. Hamuro, M. Ikeda, Y. Michishita, Y. Ishitomi, M. Naito, N. Maekawa, S. Tsukuma and M. Kawai 1971 Studies on chemotherapeutic agents against Mycobacterium tuberculosis XXVI. Synthesis and antituberculosis activity of phenylthiourea, $p$-ethoxyphenylthiourea and 3-bromo-4-ethoxyphenylthiourea derivatives. Yakugaku Zasshi, 91 : $159-165$

Fujikawa, F., K. Hirai, T. Hirayama, T. Matsunashi, Y. Nakanishi, K. Nakai, K. Kanemitu, T. Uchiwa, J. Murasawa, M. Umeda, T. Mizutani, T. Mikawa, T. Tanabe, K. Segawa, T. Tanaka, N. Maekawa and J. Nakai 1972 Studies on chemotherapeutic agents against Mycobacterium tuberculosis XXVII. Synthesis and antituberculous activity of 1-alkyl-3(3'-hydroxy-4'-alkoxycarbonylphenyl)-2-thiourea and 1-aryl-3-(3'-hydroxy-4'-alkoxycarbonylpheny1)-2-thiourea. Yakugaku Zasshi, 92: 1275-1284

Fujikawa, F., K. Hirai, T. Hirayama, M. Naito, S. Tsukuma, M. Kamato and Y. Ohta 1968 Studies on chemotherapeutics for Mycobacterium tuberculosis XXI. Synthesis and antibacterial activity on Mycobacterium tuberculosis of 2-pyridylthiourea, 4-antipyrinylthiourea and 2-benzothiazolylthiourea derivatives. Yakugaku Zasshi, 88: 1428-1432

Fye, R. L. and J. E. Oliver 1974 Chemosterilants for the house fly. J. Agr. Food Chem., 22: $374-376$

Negherbon, W. O. 1959 Handbook of toxicology, Vol. II. W. B. Saunders Co., Philadelphia and London, pp. 24, 32

Noguchi, T., K. Khomoto, Y. Yasuda, S. Hashimoto, K. Kato, K. Miyazaki and S. Kano (Nippon Soda Co. Ltd.) 1969 Thiophanate-methyl fungicide. Belg. Pat., 734,743

Oliver, J. E., R. T. Brown, R. L. Fye and A. B. Borkovec 1973 Insect chemosterilants, 1,2,4-dithizolium salts and related compounds as additives to housefly diet. J. Agr. Food Chem., 21 : 753-755

Oliver, J. E., S. C. Chang, R. T. Brown and A. B. Bořkovec 1971 Insect chemosterilants, 10. Substituted dithiobiurets. J. Med. Chem., 14: 772-773

Price, G. M., 1970 Pupation inhibiting factor in the larva of the blowfly Calliphora erythrocephala. Nature, 228: 876-877

Pyne, W. J., S. S. Szabo and R. E. Holm 1974 Synthesis and herbicidal activity of pyrrolidinecarboxanilides. J. Agr. Food Chem., 22: 921-926

Ratnasiri, N. P. and G. Fraenkel 1974 The physiological basis of anterior inhibition of puparium formation in ligated fly larvae. J. Insect. Physiol., 20:105-119

Tokumitsu, I., K. Ohgushi, H. Yamamoto and T. Kusano 1973 Studies on the rodenticidal activity of methylene-bis(1-thiosemicarbazide). Botyu-Kagaku, 38: 202-212

Uzumasa, Y. and T. Okura 1950 Separation of cations by thiourea. Bull. Chem. Soc. Jap., 23: $163-165$ 